\title{
Indexicality and Enregisterment as Theoretical Approaches to the Sociolinguistic Analysis of Romance Languages
}

\author{
Ulrich Hoinkes (Kiel)
}

Social indexicality and enregisterment are basic notions of a theoretical model elaborated in the United States, the aim of which is to describe the relationship between the use of language variation and patterns of social behavior at the level of formal classification. This analytical approach is characterized by focusing on the interrelation of social performance and language awareness. In my contribution, I want to show how this modern methodology can give new impetus to the study of today's problem areas in Europe, such as migration and language or urban life and language use. In particular, I am interested in the case of Catalan, which has been studied for some time by proponents of the North American enregisterment theory. This leads me to indicate that explicit forms of social conduct, such as language shift or the emblematic use of linguistic forms, can be interpreted with regard to the social indexicality of Catalan. I thus analyze them in a way which shows that authenticity and integration in Catalan society can be achieved to a considerable extent by practicing forms of linguistic enregisterment.

[Keywords: Social indexicality; enregisterment; sociolinguistics; language variation; urban dialect; multilingualism; migration; Catalan]

\section{Introduction}

Since its beginnings as an independent research field in the mid-1960s, European sociolinguistics has been shaped by theories, models, and traditions from North America. In this article, I would like to draw attention to a North American school that is currently influential and has so far received little attention in Europe. It finds its roots, on the one hand, in the research direction of social dialectology, founded by William Labov, and on the other hand, in cultural anthropology, a special research direction of ethnology founded in the United States and represented by names such as Michael Silverstein, Asif Agha, Barbara Johnstone, and Kathryn Ann Woolard. Central to this approach is the concept of the social indexicality of linguistic expressions.

\section{Indexicality}

\subsection{Definition of Index and Indexical}

The terminology of indexicality goes back to the semiotics of Charles Sanders Peirce (1839-1914), who distinguished between icon, index, and symbol in the field of communicative signs. An index is the type of sign that, depending on its character, represents a purely normative and noninformative relation to the object, such as a designated, fixed name. But an index also can imply an identifying reagent linked to 
the object (like fume produced by fire) or may constitute a symptom turning it into the landmark of the object (like rash for a specific disease). The relationship between index and object is not only interpretative, but also real in some form, which means there is a direct index-object relation within the semiotic structure.

In linguistics, the term indexical has its own tradition. It was already used by Yehoshua Bar-Hillel in 1954 to describe linguistic expressions that were particularly contextdependent. ${ }^{1}$ The prime example of linguistic indexicality is thus deixis, since its forms can only be conceived by relating them to the person, place, and time of the speech action. The social science understanding of indexicality now extends this contextdependence of linguistic utterances to the intersubjective experience of group, (living) space, and shared time experience, three social dimensions in which all speaking and communicating is bound. This interpretation is based on the conviction that completely context-independent utterances or forms of communication do not exist.

\subsection{Social Indexicality ${ }^{2}$}

As an instrument of sociolinguistic analysis, the term indexicality is used to categorize the observed reality scientifically (the object of investigation is social interaction) as well as describe its pragmatic or, more precisely, ethnopragmatic patterns. The contextual categorization takes place through the language community itself, both through its particular language behavior and through the language reflection it produces. As a consequence, the process of indexing linguistic variation is not due to taxonomic location by the researcher, but should be seen as a phenomenon that the linguist must observe and recognize in the use of language itself, both public and private.

\subsection{Example: Latino Immigrants in the United States}

An example of this process may be found in the case of Central and South American immigrants in the United States who are characterized by a special form of codeswitching or codemixing generally known as Spanglish. Speakers to whom this mixed language use is assigned are indexed by the English-speaking community as Latin Americans and as having other social-contextual characteristics.

The process can progress so far in the consciousness of the linguistic community that the use of the so-called Spanglish assumes a socially symbolizing character, which can become the subject of public discourse and which can be seen in different forms of communication, for example, in comedy. Hilary Parsons Dick (2011) points out that the social indexicalization of migrants in the United States consolidates the understanding of social patterns that can also be found as a result of critical discourse analysis. Among them is the construction of a "permanent otherness" of migrants and their classification as a lower social group, which Dick interprets as a form of U.S.

\footnotetext{
${ }^{1}$ Bar-Hillel, Yehoshua (1954), "Indexical Expressions," Mind 63, 359-376.

2 Hillary Parsons Dick (2011: 228) defines social indexicality as follows: "Language varieties point to, presuppose, and enact culturally specific personae, images of people associated with patterned ways of using language."
} 
racialization. On the basis of more recent indexicality research on problems associated with migration, she arrives at a similar interpretation of social reality as Teun van Dijk, whose racism research, carried out from Barcelona since the 1990s within the framework of critical discourse analysis, depicts similar results for Latin America and for Europe (cf. Van Dijk, 2005).

\section{Enregisterment}

\subsection{Register and Enregisterment According to Agha}

Closely related to the concept of indexicality is that of enregisterment, which was introduced into the debate by Asif Agha around 2000 and which has enjoyed considerable acceptance since then. Agha (2003: 231) derives the term directly from the term register and defines processes of enregisterment as "processes through which a linguistic repertoire becomes differentiable within a language as a socially recognized register of forms." In a later essay, Agha (2005) offers an even more precise definition that clarifies the connection between indexicality and enregisterment: "processes whereby distinct forms of speech come to be socially recognized (or enregistered) as indexical of speaker attributes by a population of language users."

Agha later developed his concept of register more towards that of a "socially registered" communicative behavioral pattern, negotiated and stereotyped in complex mechanisms of interaction within a community of speakers. The social role of the speaker, in Agha's view, is ultimately more decisive than the realization of the linguistic variety he uses. ${ }^{3}$ However, Agha continues to focus on language as a means of social communication and as a means of creating a social identity. Processes of enregisterment, i.e., the formation of social registers in the Aghaian sense, mirror the opposing and mutually delimiting identity patterns that are negotiated in society through language and linguistic variation. The most diverse constellations of groups, habitats, and synchronies play a decisive role, which is why the aspect of indexicalization always remains pertinent. Enregistered identities are oriented towards these social groups, living spaces, and shared experiences of time. They are determined by forms of speaking, which in turn can be discussed concretely through metalinguistic discourses (Barbara Johnstone calls this "talk about talk").

\subsection{Model Studies on Enregisterment}

The concept of enregisterment has so far been applied in a number of concrete case studies, especially to communication spaces in Asia (cf. Sze-Wei Liao, 2010; Goebel, 2010). These studies make it clear that the enregisterment model is excellently suited to uncovering social structures, differing from those in Europe, through the analysis of linguistic behavior patterns and comprehension of their dynamics. However, studies such as Zane Goebel's research on the relationship between Javanese and

\footnotetext{
${ }^{3}$ In his book, Language and Social Relations, Agha defines enregisterment as "processes whereby diverse behavioral signs (whether linguistic, non-linguistic, or both) are functionally reanalyzed as cultural models of action, as behaviors capable of indexing stereotypic characteristics of incumbents of particular interactional roles, and of relations among them." (Agha, 2007: 55)
} 
Indonesian in the neighborhoods of Semarang on Java suggest that the approach would also make a valuable contribution to analysis when applied to urban sociolinguistics in Europe. For example, Brussels might be one of the cities in which the social rules of multilingualism could be described in an informative way on the basis of the enregisterment model.

\section{The European Sociolinguistics of the City}

\subsection{European Methodological Tradition}

European sociolinguistics of the city pays little attention to these or other North American lines of research. If one looks, for example, at the extensive research on urban languages in the French-speaking world or in Italy, it becomes apparent that only a few of these European studies can be assigned to an unambiguous theoretical framework, which then usually follows the traditions of discourse analysis founded by Michel Foucault and the cultural theory influenced by Pierre Bourdieu. However, the strongly philosophical character of these two theoretical approaches is often an obstacle to developing convincing models for empirical work from them, so that in recent European sociolinguistics, and not only that of the city, signs of fatigue emerge in the theoretical recourse to Foucault and Bourdieu.

\subsection{The Example of the Urban Language of Rome}

The 2012 volume, Lasciatece parlà, on Rome's current urban language, romanesco, provides a multifaceted and detailed portrait of this urban variety. This portrait essentially takes place on a purely descriptive level, however, which seldom brings to bear theoretical premises or social-structural analyses. Even Antonella Stefinlongo's contribution on "The perception of Rome's linguistic identity" is not based on any theory or method, as references to previous sociolinguistic studies in the field are missing. For example, where she characterizes the linguistic behavior of the many immigrants and young people in Rome and finds that these typically Romanesque traits are incorporated into the Italian they speak or learn, she can only comment on this speculatively:

The dialect in particular therefore seems to exert a certain sympathetic attraction on newcomers and at the same time to be used by a wider population and across a larger area: by the Romans of the lower social strata and, scattered everywhere, by the inhabitants of the centre as well as those of the outer districts.... In Rome, the phenomenon of the re-emergence of dialect use takes the form of a genuine reappropriation of romanesco, especially for the younger generations ... by whom it is used without any social classification, either as a real group language ... or as a diaphasic register of the standard language. (Stefinlongo in D'Achille et al., 2012: 66, in my own translation from Italian) 
Such statements arouse curiosity about a well-founded sociolinguistic analysis of the urban language of Rome, but also reveal that such an analysis does not yet exist. At the same time, it becomes apparent that no adequate inventory of terms is used to advance concrete urban dialect research on a basis that makes sense for empirical work. $^{4}$

\subsection{The Question of Transfer of Method from the United States}

If, on the one hand, one considers the high sociolinguistic level at which Goebel examines urban multilingualism on Java and, on the other hand, recognizes the widespread method deficit in European urban language research, the question arises whether further method transfer from North America would do European sociolinguistics any good. Such method transfers have taken place since the beginning of the discipline. Diglossia's research in the tradition of Charles Ferguson and Joshua Fishman, for example, has long and decisively influenced the beginnings of sociolinguistics on Romance and other European languages. Similarly, the method of ethnography of speech developed by John Joseph Gumperz and Dell Hymes has been adopted in many European sociolinguistic studies. The latter, by the way, is related to the approaches of indexicality and enregisterment research, but as a method attaches much less importance to formalization. ${ }^{5}$

\section{Ordered Indexicality}

\subsection{The Programmatic Contribution of Michael Silverstein}

Michael Silverstein provided a programmatic contribution to the further development of enregisterment research. In his article, "Indexical order and the dialectics of sociolinguistic life," published in 2003, he explains the principle of ordered indexicality. According to this principle, indexicalization can be interpreted as a gradual social anthropological process. The signal effect that Silverstein's essay has produced is related to his pointing out ways in which the methodologically relatively open research of linguistic ethnography (in the tradition of Gumperz) and the research approach of social dialectology (in the tradition of Labov), which is not yet sufficiently defined in terms of interdisciplinary input, can find a more formalized alternative in this new form of sociolinguistic thinking. ${ }^{6}$ Without getting involved in the extremely complex methodological discussion that is based on Silverstein's proposals, the following sections underline the possible relevance of such ethno-methodological precision for the sociolinguistics of Romance languages.

\footnotetext{
${ }^{4}$ Attempts by European urban language research and sociolinguistics in general to develop a special spatial linguistics (linguistique spatiale) have not yet progressed far. A couple of years ago, the French representatives of linguistique urbaine were dealing with the nascent theory formation of the studies on linguistic landscape, from which, however, they tried to distinguish themselves (cf. Bulot, 2013).

${ }^{5}$ In ethnography, the researcher is more of a free observer.

${ }^{6}$ With regard to Labov, it is also a matter of underlining the affinity of his sociolinguistic research tradition to cultural anthropology. Labov (2010) himself shows clear tendencies to shift the connection he sees between language, society, and culture to the field of interpretation of the cognitive sciences.
} 


\subsection{The Three Orders of Social Indexicality (According to B. Johnstone)}

Barbara Johnstone and two colleagues undertook a pilot study on ordered indexicality to investigate the emergence of social dialect forms in the U.S. city of Pittsburgh, Pennsylvania, with 2.6 million inhabitants (Johnstone et al., 2006). She applies the analysis scheme designed by Silverstein and distinguishes between three types of indexing:

- Geographic indexation (first order), which is used by linguists to identify constantly occurring language variations in local or regional speaker groups. These language variations determine the speaker groups, but are not based on their sociocultural homogeneity or necessarily on the particular language traditions of the region. Thus, the varieties of urban languages also fit into this examination scheme, for it is precisely here that very complex and heterogeneous social structures result from migration and globalization phenomena, some of which have led to a clear de-dialectalization. The observable phenomena of geographic indexation, which Silverstein calls $n$-thorder indexicals, are therefore mostly phenomena of redialectalization, in which young people are particularly involved.

- The social indexation (second order) that Silverstein summarizes as $\mathbf{n + 1}$-thorder indexical. This is essentially about the process of making the speaker group itself aware of the symbolic functions of language. The speaker's selfperception leads to a construction of identity, which is carried out on the basis of the communicative peculiarities of the language area itself (e.g., the city district). However, these identity-giving peculiarities are interwoven with social structure and demarcation processes, so that the linguistic variation immediately becomes a marker (in Labov's sense) for social stratification or group allocation and also consolidates social hierarchies. This is associated not only with the use of these language variants, but also with their conscious suppression in certain sociocultural contexts.

- An indexation of the third order (enregisterment) is present if the socially indexed language variation becomes a social register in the sense of Agha. The process is, of course, only formally distinguishable from second-order social indexation. According to Silverstein, it is primarily characterized by the fact that a meta-pragmatically generated interpretation of the linguistic variation takes place within the speaker community. The distinctive linguistic features in the communicative space are explicitly socially located and consciously, i.e., in a reflective way, used to construct identity. On this level, stereotypes develop in the sense of Labov, i.e., linguistic forms that are primarily addressed in social discourse, but whose actual occurrence may even decrease. Johnstone et al. (2006) describe the third-order-indexicality in relation to their Pittsburgh case study as follows:

People noticing the existence of second order stylistic variation in Pittsburghers' speech link the regional variants they are most likely to hear with Pittsburgh identity, drawing on the increasingly widely 
circulating idea that places and dialects are essentially linked (every place has a dialect). These people, who include Pittsburghers and nonPittsburghers, use regional forms drawn from highly codified lists to perform local identity, often in ironic, semiserious ways. (Johnstone et al., 2006: 82 f.)

\subsection{The Methodological Relevance of the Enregisterment Approach}

The crucial question that arises when applying this approach to situations of social language use in Europe can be formulated as follows: Does the distinction between second-order and third-order social indexation create new possibilities for interpretation in order to better understand and explain the maintenance of regional language varieties and regional languages in cities, but also in administratively and politically delimitable regions of Europe? The previously mentioned case of an obvious redialectalization of the urban language of Rome seems to imply a positive answer to this question. In principle, however, the phenomenon of urban languages-with the exception of Rome and possibly other exceptions in Italy-is less pronounced in the European countries where Romance languages are spoken. The sociolinguistique urbaine, for example, as developed by Thierry Bulot in France, hardly takes recourse in the actual pratiques linguistiques of city dwellers (cf. Bulot, Bauvois, Blanchet, 2001). Instead, the complex pratiques discursives, i.e., the discursive behavior patterns, are placed in the middle point of the investigation. Bulot is concerned with the theoretical determination of a discursively shaped urban space, which is primarily determined by the conflictual diversity of ethnic and sociocultural influences. ${ }^{7}$

Basically, the research orientations of the enregisterment approach and the French sociolinguistique urbaine are not so far apart as they both look for the complex social implicatons of language use. Methodologically, however, there are worlds between these two linguistic approaches. An emblematic city dialect characterized by only a few linguistic features, does not provide an object for the French research method, to which the phenomenon of indexation is of no analytical interest.

With that said, it can be assumed that European sociolinguistics would benefit from recourse to U.S. specific anthropological theory formation in relation to multiethnic language areas, i.e. particularly in relation to urban spaces, and that the corresponding research methods would even allow to connect to the European traditions of dialectology and variational linguistics.

\footnotetext{
${ }^{7}$ According to Bulot's theory, sociolinguistics must connect with geography in the following way: "The encounter between sociolinguistics (urban) and geography (social) therefore results from a double movement of integration: that of the spatial dimension in the study of the discourses held on languages and effective linguistic practices, and the integration of the symbolic and linguistic dimension in the reading of individual and collective relationships to space. Convergence is further strengthened by the common priority given to highlighting power issues and social inequalities." (Bulot \& Veschambre, 2006: 48 , in my own translation from French)
} 


\section{Catalonia: A Case of Third-Order Indexicality?}

\subsection{Catalonia's Special Position in North American Sociolinguistics}

Another example taken from the field of Romance sociolinguistics, the case of Catalan, is predestined to face the parameters of indexicality research. This assessment is supported by American research, which for decades has given Catalan a special place in sociolinguistics with a view to Europe. ${ }^{8}$ For example, the American Kathryn Ann Woolard is a well-known representative of the indexicality approach and a renowned Catalanist. Woolard received her doctorate in the early 1980s with a thesis on the linguistic conditions in Catalonia, more precisely, Barcelona, in the years 1979-80 when Catalonia became an Autonomous Community in Spain (Woolard, 1989). Her study at that time was entirely in line with the methodology of sociolinguistic ethnography and brought much personal observation and evaluation of informal conversations into the presentation of the Catalan language situation in Barcelona. The interpretative focus of her work is also groundbreaking for later approaches, as can be seen from chapter titles such as "A Crisis in the Concept of Identity" and "Rights and Duties of Language Choice."

\subsection{Language Ideology and Social Identity in Catalonia}

Kathryn Woolard, now professor of anthropology at the University of California San Diego, has focused her theoretical research on questions of social identity formation and language ideology. Her analytical concepts are close to indexical research in sociolinguistics and she clearly demonstrates the applicability of this approach to situations of language use in Europe. In a programmatic article on language ideologies from 2008, she refers to the essential connection between social indexicality and identity-related authenticity of language behavior. ${ }^{9}$

The social indexation of speech, which can be caused by the use of linguistic variety as well as the choice of language, thus primarily defines the speaker's self-determination as well as the way he or she is viewed by others as a member of society, more precisely as a type of personae, following the terminology used in American research. It is important to note that it is not the referential function of discourse in public that is decisive for the identity formation process, but the personal and integrative

\footnotetext{
8 Joshua Fishman, for example, refers explicitly to the special case of Spanish multilingualism and especially to the importance of Catalan as a sociolinguistic object of investigation in his article Reversing Language Shift, published in 1991 (Fishman, 1991: 295).

9 "Authenticity is understood as the genuine and essential expression of an identity or an ' $I$ '.... The authentic voice is felt as iconic of the spirit of a particular community. While the referential function of language is ideologically crucial in the public sphere of anonymity, the pragmatic function of social indexicality is paramount in the ideology of authenticity. Speech becomes not only an indexical sign but even the icon of a particular type of person. This iconic relationship of language with the person is, in fact, the essence of authenticity. It is within this logic that the acquisition of a second language requires that we stop speaking a first language. Speakers cannot risk the linguistic traces of the previous identity spoiling their assertion of a new identity of value. The importance of the authentic voice lies in what it indicates about the speaker, rather than in what is said. In some bilingual circumstances, in fact, the use of the minority language has for some interlocutors exclusively the value of the social index and not its referential value." (Woolard, 2008: 183, in my own translation from Catalan)
} 
authenticity of speaking, which is also related to the belonging to a particular language community and constitutes a form of non-referential indexicality. Woolard sums it up as follows:

The importance of the authentic voice lies in what it indicates about the speaker, rather than in what is said. (Woolard, 2008: 183, in my own translation from Catalan)

\subsection{The Concept of Nation and Monolingualism in Catalonia}

Woolard's statement that the choice of language in multilingual contexts, as well as the choice of a linguistic variety in monolingual communities, depends on language ideology and identity-constituting behavioral patterns in society is fundamental. It shows why indexicality and enregisterment processes are essential in the complex forms of modern society and that they often point beyond the referential meaning of what is said. According to this interpretation, a migrant, for example, can hardly ever authentically produce a declaration of belief in a Catalan identity if he does so, for biographical reasons, in Spanish. Similarly, the political speech of a Member of Parliament in the Generalitat who speaks in favor of Catalonia's independence would be untrustworthy if the speech were not given in the national language, i.e., Catalan.

In the particular case of Catalonia, this categorical view is entirely justified. Not only does it coincide with the official language policy of the Catalan government, which has been maintained for decades-the most obvious example being the established linguistic immersion program in the country's public schools-but it is also confirmed by manifold proofs of the inaccessibility of a balanced bilingual organization of public life. For instance, the use of Catalan in Catalonia repeatedly evokes reactions of open hatred among non-Catalan speakers.

\subsection{Catalan in Migration Contexts}

In his book, Fragmented Nation-Globalized Region, published in 2013, Patrick Eser examines in detail the political-ideological genesis and shaping of Catalan nationalism from the post-Franco era to the present day. He also deals with the problem of immigration to Catalonia and emphasizes that Catalonia uncompromisingly represents the idea of monolingualism in his officially propagated integration concept:

During the governmental period guided by moderate nationalism, the emphasis given to the role of language use proved to be a constant of integration policy, based on the law for the normalization of the Catalan language. The preferential treatment of the country's own language, the "llengua pròpia", provided for in this law, has an impact on the migration policy of the Generalitat. It is only through the acquisition of the Catalan language that successful integration into Catalan society can be achieved. (Eser, 2013: 222, in my own translation from German) 
The concept of Ilengua pròpia combines Woolard's interactional-sociolinguistic argumentation with Eser's political-ideological explanation of the case of Catalonia. The former president of the Generalitat, Artur Mas, even condensed this pattern of behavior in his political speeches up to the imperative that immigrants in Catalonia, as part of (particular) Catalan society, should not only master the Catalan language, but also defend Catalonia's identity (cf. Eser, 2013: 221).

Even if it is assumed that this uncompromising form of ideologization has an integrative effect in Catalonia-after all, the success of Catalan language policy since the 1980s has been remarkable to this day-this effect can hardly be measured by the number of migrants who learn, master, and apply Catalan as a second language after immigrating to Catalonia. The high proportion of Latin American immigrants in Catalonia is one of the factors that oppose this model of language change. On the other hand, recent studies have shown that the tendency to use Catalan instead of Spanish or another migrant language can be clearly demonstrated in mixed couples and families with a migrant background (cf. Boix-Fuster / Torrens Guerrini, 2011). At this level of private interaction, the reason for this certainly lies in the ideology of authenticity described by Woolard.

\subsection{Catalan Society from the Perspective of Enregisterment}

If the interactional reflex of Catalan society is to make the Catalan language a social register with which the speakers associate integration and many other connotations of social success, the question arises of how this register can also be reached by migrants or how they can even contribute to the process of enregisterment.

In my opinion, the answer to this question could be found in empirical studies whose aim should be to describe the communication behavior and discursive practices of interactants who, as private individuals, more or less influenced by the pressure of public discourses and institutional norms, move in multilingual groups and thereby determine their identity as group members at various levels. The study collection Les llengües al sofa, el plurilingüisme familiar als països de llengua catalana, published by Emili Boix-Fuster and Rosa M. Torrens Guerrini in 2011, is a good start in this direction. These studies include metalinguistic discourses of test persons who give accounts of their language choice behavior in family contexts, obtained from prestructured interviews. In the sense of enregisterment theory, these recordings could also be analyzed as metapragmatic data.

However, the choice of Spanish or another migrant language, or the use of codeswitching between several languages in everyday conversation in Catalonia, are not easily understood as a social indexation that characterizes the permanent otherness of migrants in the way that is obviously typical of Chicanos and other immigrants in U.S. society (see the explanations above). ${ }^{10}$

10 Catalonia offers an excellent example of how social mechanisms of language choice can be interpreted in a very differentiated way through the historically established (and temporarily dominant) co-presence of a non-regional "foreign" language (Castilian) in conjunction with social registers of language behavior. Frekko (2009) points out that identity formation patterns, which are normally based on an internal language variation, are partly superimposed in Catalonia (or the Catalan countries) by 
Migrants in Catalonia, as in other European multilingual contexts, probably get more than one chance to achieve a form of enregisterment, although the politically intended change of language is meant to indicate the best path to authenticity in language behavior. In this special case, several forms of commitment to Catalan identity would have to be considered, which in a preliminary phase of the enregisterment process prove to be indexicalities of the second order. For example, typical Catalan short phrases such as prou ("it's enough"), anem ("let's go"), bon profit ("enjoy the meal"), or amb compte ("take care") could become markers in everyday conversation, forming indexed expressions used even by non-Catalan speakers. Likewise, it is conceivable that ritualized apologies for not using the Catalan language in certain conversations with Catalan-speaking people assume a marked indexicality function. However, it should be noted that all these markers may also be used unauthentically (e.g., ironically), and in this case would lose their indexing character.

\section{Conclusion}

The conditions for enregisterment with regard to marked elements of the "own language" (Ilengua pròpia) in Catalonia or in other multilingual regions have not yet been sufficiently explored. However, they can only be recognized with certainty if the indexical process also includes phenomena of the third order. These phenomena of the third order are explicitly given in Catalonia by institutional conditions, not least by the influence of the media, and measures of language policy. If Barbara Johnstone points out that in Pittsburgh the existence of T-shirts with inscriptions in local dialect must be regarded as an enregisterment of higher order (talk about talk), this stage has long since been reached in Catalonia due to the political and economic frameworks. What is missing, however, is a nuanced sociolinguistic view on the patterns of personal language behavior. To sharpen this view, the approach of ordered indexicality seems to be a particularly suitable method.

To reiterate: Third order indexicality provides an adequate methodological framework for pointing to linguistic and social behavioral phenomena in multilingual societies, which cannot be determined solely by the performance of linguistic variation. Decisive in this context is the discursive handling of identity-creating indices of linguistic and language-related social action, which assumes a definitory character for social personae, especially in the private sphere, and can have an integrative effect in this sense. In any case, European sociolinguistics must be interested in developing a methodological perspective for these higher indexical forms of language use.

\section{Bibliography}

Agha, Asif (2003): „The social life of cultural value“, Language \& Communication 23, 231-273.

- (2005): „Voice, Footing, Enregisterment“, Journal of Linguistic Anthropologe 15, 38-59.

- (2007): Language and Social Relations, Cambridge: Cambridge Univ. Press.

the register-specific use of Castilian and/or Catalan. Frekko explicitly proposes to analyze this phenomenon under the aspect of enregisterment. 
Boix-Fuster, Emili / Torrens Guerrini, Rosa M. (eds. 2011): Les llengües al sofà. El plurilingüisme familiar als països de llengua catalana, Lleida: Pagès.

Bulot, Thierry / Bauvois, Cecile / Blanchet, Philippe (eds. 2001): Sociolinguistique Urbaine. Variations linguistiques: Images urbaines et sociales - Cahiers de Sociolinguistique 6.

- / Veschambre, Vincent (2006): „Sociolinguistique urbaine et géographie sociale : hétérogénéité des langues et des espaces", in Sechet / Veschambre (eds.), 305-324 (zitiert nach <http:/ /books.openedition.org/pur/1924>).

D’Achille, Paolo / Stefinlongo, Antonella / Boccafurni, Anna Maria (eds. 2012): Lasciatece parlà. Il romanesco nell'Italia di oggi, Roma: Carocci.

Dick, Hilary Parsons (2011): "Language and Migration to the United States", Annual Review of Anthropology 40, 227-240.

Eser, Patrick (2013): Fragmentierte Nation - globalisierte Region? Der baskische und katalanische Nationalismus im Kontext von Globalisierung und europäischer Integration, Bielefeld: transcript.

Fishman, Joshua, A. (1991): Reversing Language Shift. Theoretical and Empirical Foundations of Assistance to Threatened Languages, Clevedon [et al.]: Multilingual Matters.

Frekko, Susan E . (2009): "“Normal” in Catalonia: Standard language, enregisterment and the imagination of a national public ", Language in Society 38, 71-93.

Goebel, Zane (2010): Language, Migration, and Identity: Neighborhood Talk in Indonesia, Cambridge: Cambridge University Press.

Hoinkes, Ulrich (2015): „Indexing Romance Language Use? Zur Anwendbarkeit eines aktuellen Theoriemodells aus den USA auf die soziolinguistische Analyse der romanischen Sprachen und insbesondere des Katalanischen“, Zeitschrift für Katalanistik 28, 19-35.

Johnstone, Barbara / Andrus, Jennifer / Danielson, Andrew E. (2006): „Mobility, Indexicality and the Enregisterment of 'Pittsburghese'“, Journal of English Linguistics 34, 77-104.

Liao, Sze-Wei (2010): Identity, Ideology, and Language Variation: A Sociolinguistic Study of Mandarin in Central Taiwan, Davis: University of California (PhD Diss., <http:/ /linguistics.ucdavis.edu/pics-and-pdfs/DissertationLiao.pdf>).

Morford, Janet (1997): „,Social Indexicality in French Pronominal Address“, Journal of Linguistic Anthropology 7:1, 3-37.

Sechet, Raymonde /Veschambre, Vincent (eds. 2006): Penser et faire la géographie sociale : Contributions à une épistémologie de la géographie sociale, Rennes: Presses Universitaires de Rennes.

Tacke, Felix (2015): Sprache und Raum in der Romania. Fallstudien zu Belgien, Frankreich, der Schweiz und Spanien, Berlin /Boston: De Gruyter.

Silverstein, Michael (2003): "Indexical order and the dialectics of sociolinguistic life", Language and Communication 23,193-229.

Van Dijk, Teun A. (2005): Racism and discourse in Spain and Latin America, Amsterdam [et al.]: Benjamins.

Woolard, Kathryn A. (1989): Double talk. Bilingualism and the Politics of Ethnicity in Catalonia, Stanford, CA: Stanford University Press.

- (2008): „Les ideologies lingüístiques: Una visió general d'un camp des de l'antropologia lingüística“, Revista de Llengua i Dret 49, 179-199.

- (2016): Singular and Plural. Ideologies of Linguistic Authority in $21^{\text {st }}$ Century Catalonia, New York: Oxford University Press. 